\title{
MEMBUMIKAN AL - QURAN DALAM ETIKA SANTRI KEPADA KYAI; STUDI TAFSIR QS AL KAHFI AYAT 66 - 70
}

\author{
Nazilatus Syukriyah \\ Program Magister UIN Sunan Kalijaga Yogyakarta \\ nazilatussyukriyah@gmail.com
}

\begin{abstract}
The ethics in educational process occupies the most significant place in Islamic intellectual tradition. One of the greatest Islamic education's forms in Indonesia is Pesantren so its success signifies the success of this nation. The ethics between Santri (Pesantren's learner) and Kyai (Pesantren's lecture) is the identical tenet there, so it's necessary to explore it in Al-Quran as our way of life. Hereby this study is purposed to obtain a deep understanding about the ethics of santri to Kyai by analyzing the interpretation of Al Kahfi verse 66 - 70. This is a qualitative research using literature method (library research) with the book Mafatib al-Gaib, written by Fabrudin $A l-$ Razi, as the primer data source and the other related literature data as the secondary source. This study found that there are 10 ethical values in Al Kabfi verse $66-70$ associated with the ethics of santri to Kyai i.e : a. Tawadlu', b. Asking permition to study, c. feeling more stupid d. asking the kyai to teach e. believing that Allah gives the more knowledge for Kyai, f. Tawakeal and asking Allab's guidance, g. studying seriously, h. absolute obedience, i. khidmah and j. doesn't ask the other but knowledge.
\end{abstract}

Keywords : Ethics, Santri, Kyai, Pesantren, Al-Quran

\begin{abstract}
Abstrak
Tradisi keilmuan Islam menempatkan etika akademis pada posisi tertinggi dalam proses pendidikan. Salahsatu bentuk pendidikan yang berkembang pesat di Indonesia adalah pondok pesantren sehingga keberhasilan pendidikan pondok pesantren akan berperab besar sebagai sumber kekuatan untuk kemajuan bangsa. Pesantren merupakan lembaga yang sangat identik dengan etika, utamanya etika antara santri kepada kyai. Penyebaran pemahaman tentang etika santri kepada Kyai merupakan pembahasan penting dan $\mathrm{Al}$ - Quran telah menyedikan jawabannya. Oleh
\end{abstract}

Nazhruna: Jurnal Pendidikan Islam

Vol. 2 No 2 2019. Issn: 2614-8013. Hal. 209-224

DOI: https://doi.org/10.31538/ nzh.v2i2.269 
karena itu, kajian ini bertujuan untuk menggali pesan Al Quran mengenai etika santri kepada Kyai dengan melakukan studi analisi tafsir Q.S. Al Kahfi ayat $66-70$. Penelitian ini merupakan penelitian kualitatfi dengan metode kepustakaan, sumebr data primer dalam penelitian ini adalah kitab Mafatih Al - Gaib karya Farhrudin Al - Razi yang dilengkapi dengan sumberd ata sekunder sebagai penunjang. Hasil penelitian ini menemukan etika seorang santri kepada kyai yang termaktub dalam QS. Al Kahfi ayat 66-70 yaitu : a. Tawadlu', b. meminta izin untuk diperbolehkan belajar, c. merasa lebih bodoh dari kyai, d. meminta kepada Kyai agar bersedia mengajari sebagian ilmu, e. Tawakkal dan meminta hidayah kepada Allah, g. bersungguh - sungguh, h. patuh kepada kyai secara mutlak, i. khidmah, j. tidak meminta kepada Kyai selain ilmu.

Kata kunci : etika, santri, Kyai, pesantren, Al - Quran

\section{PENDAHULUAN}

Penyataan Imam Azzarnuji dalam muqoddimah karya abadi terbaiknya, Ta'limul Muta'allim Thoriqot Ta'allum merupakan salah satu bukti pengakuan akan urgensi etika dalam menuntut ilmu. "Setelah saya melihat banyak penuntut ilmu di saat ini pada tekun belajar tetapi tidak berhasil menggapai manfaat dan buahnya - yaitu aplikasi ilmu dan pengembangannya, karean mereka salah jalan dan mengabaikan persyaratan, padahal siapapun salah jalan tentu tersesat dan gagal mencapai tujuan, kecil maupun besar. Maka dengan senang hati saya bermaksud menjelaskan tentang thariqoh ta'allum, sesuai dengan apa yang saya baca dari berbagai kitab dan yang saya dengar dari para guruku yang alim dan arif itu". ${ }^{1}$ Lebih lanjut dijelaskan diantara salah jalan dan mengabaikan persyaratan yang disebutkan Imam Azzarnuji adalah tidak adanay etika yang baik dalam diri pencari ilmu baik dalam hal akhlak pribadi, akhlak kepada ilmu maupun kepada guru. Pernyataan tersebut menggambarkan bahwa etika dalam ilmu bagaikan rasa asin dari garam, bagaikan rasa manis dari gula, knowledge is important but character is more. Penyebab tidak dapat bermanfaatnya ilmu adalah karena tidak adanya etika dalam diri orang yang berilmu.

Ratusan tahun telah berlalu sejak karya Imam Azzarnuji tersebut diterbitkan tahun $1709 \mathrm{M}$, pembahasan tentang etika dalam menuntut ilmu masih menjadi isu yang hangat. Semakin hari, etika seolah semakin hilang dari

${ }^{1}$ Syekh al - Zarnuji, Ta’limul Muta'allim, ( Semarang : Pustaka Alawiyyah), hlm. 1 
diri manusia secara umum sehingga pembahasan dan pengkajian tentang etika masih perlu untuk di gencangkan untuk menjadikan kehidupan ini lebih baik di masa yang akan datang. Salah satu bukti nyata sulitnya menerapkan kebermanfaatan ilmu yang tampak di Indonesia adalah tingginya angka pengangguran.

Badan Pusat Statistik (BPS) mengungkapkan bahwa di tahun 2019 ini, jumlah pengangguran di Indonesia mencapai 6,82 juta orang, diantara jutaan orang tersebut, hanya 2,56\% yang berpendidikan SD kebawah, sedangkan sisanya adalah lulusan SMA keatas. ${ }^{2}$ Selain karena persoalan sempitnya lapangan pekerjaan dan faktor lainnya, hal yang paling mendasar dari keberhasilan pendidikan adalah interaksi antara peserta didik dan pendidik. Terciptanya hubungan yang baik antara keduanya akan mempengaruhi kualitas ilmu pengetahuan dan pembentukan karakter dalam diri peserta didik yang mejadi bekal utama dalam menghadapi kehidupan pasca proses pendidikan. Adapun tujuan hakiki dari pendidikan adalah penghambaan kepada Allah SWT.

Pondok pesantren merupakan salah satu model pendidikan yang berkembang pesat di Indonesia, keberadaan pesantren telah membawa kemajuan bagi bangsa yang catatan sejarah kemerdekaannya pun tidak terlepas dari peran pesantren ini. Saat ini terdapat kurang lebih 27.218 pondok pesantren di Indonesia dengan jumlah santri total kurang lebih 3.642.783 santri. ${ }^{3}$ Data tersebut menunjukkan bahwa keberhasilan pendidikan di pondok pesantren akan berperan besar bagi kemajuan bangsa. Pesantren merupakan lembaga yang sangat identik dengan etika, utamanya etika santri (peserta didik di pesantren) kepada Kyai (pengasuh dan guru utama di pesantren). Penyebaran pemahaman tentang bagaimana seharusnya etika santri kepada Kyai merupakan pembahasan penting sepanjang masa, utamanya di zaman yang mengelu - elukan Hak Asasi Manusia sebebas bebasnya yang terkadangn justru melampaui batas etika ini.

Al-Quran merupakan risalah penyempurna dari wahyu-wahyu Allah sebelumnya. Jumlah dan bunyi ayat dari 114 surat didalamnya tidak pernah dan tidak akan pernah berubah sejak berabad - abad yang lalu diturunkan kepada Rasulullah SAW yang mulia, tetapi isi kandungannya selalu mampu menjawab dan memberi petunjuk atas segala problematika yang dihadapi

\footnotetext{
${ }^{2}$ www.bps.go.id diakses pada 28 Juli 2019 pukul 22:51 WIB

${ }^{3}$ www.pendis.kemenag.go.id , diakses pada 24 Desember 2018 pukul 23:33 WIB
} 
manusia, inilah diantara sisi kemukjizatan Al-Quran, shabih fii kulli zaman wa makan. Diantara pelajaran tentang hubungan murid kepada guru dikisahkan dalam QS. Al Kahfi ayat 66-70 yang menceritakan kisah Nabi Musa A.S dengan seorang hamba Allah yang mulia lagi tinggi ilmunya, sebagian ulama' berpendapat bahwa hamba Allah tersebut adalah Nabi Khidir A.S. Dalam kajian tafsir, terdapat beberapa tafsiran yang bermacam-macam akan ayat tersebut, diantara mufassirnya adalah Fahrudin Al-Razi dalam kitab Mafatih al - Gaib. $^{4}$

Penelitian ini merupakan penelitian kualitatif dengan metode kepustakaan, sumber data primer dalam penelitian ini adalah kitab Mafatih al - Gaib karya Fahrudin Al Razi dengan sumber data sekunder sebagai penunjang. Setelah data terkumpul dan tersusun, penulis mengolahnya dengan cara menguraikan secara teratur seluruh konsepsi Al-Razi dalam tafsir QS. Al - Kahfi ayat 66-70. Setelah itu, peneliti menginterpretasi untuk merumuskan teori mengenai hal yang dibahas dalam penelitian ini. Terakhir peneliti menganalisa dengan melakukan pemeriksaan secara konsepsional penafsiran tersebut sehingga pesan - pesan dalam Al-Quran mengenai etika santri kepada Kyai yang tergambar dalam QS. Al Kahfi ayat 66 - 70 dapat ditemukan dan di sajikan secara maksimal.

\section{PEMBAHASAN}

\section{Etika Santri Kepada Kyai}

Dalam ajarannya, Islam sangat serius dalam mengatur tentang pendidikan sampai dalam memperhatikan apa yang menjadi tugas dan kewajiban - kewajiban para murid serta apa yang harus menjadi pasangan mereka dalam soal tingkah laku.

Santri adalah murid yang belajar di pesantren. Pada umumnya santri terbagi menjadi dua jenis yaitu santri mukim dan santri kalong. Santri mukim adalah murid yang berasal dari daerah yang jauh dan menetap di pesantren. Sedangkan santri kalong adalah murid yang tinggal tidak jauh dari lokasi berdirinya pesantren tersebut. Para santri kalong pergi ke pesantren ketika ada tugas belajar dan aktivitas pesantren lainnya. ${ }^{5}$

4 Kholid Akhmad Muzakki, Ahmad Rizza Firdaus, dan Annisa' Fatmayanti, "Tindak Tutur Tak Langsung Dalam Surat Al-Kahfi (Kajian Analisis Pragmatik)," Naðhruna: Jurnal Pendidikan Islam 1, no. 1 (16 Agustus 2018): 96-121, https://doi.org/10.31538/nzh.v1i1.44.

${ }^{5}$ HM. Amin Haedari, dkk, Masa depan Pesantren; dalam tantangan modernitas dan tantangan komplesitas global ( Jakarta: IRD Press, 2004), hlm. 35 
Menurut Nurcholis Majid dalam buku Bilik - Bilik Pesantren; Sebuah Potret Perjalanan, santri berasal dari kata cantrik (dalam agama Hindu) yang berarti orang - orang yang ikut belajar dan mengembara dengan empu empu ternama. Namun ketika diterapkan dalam agama Islam, kata Cantrik tersebut berubah menjadi santrri yang berarti orang-orang yang belajar kepada guru agama. ${ }^{6}$ Sedangkan menurut Kamus Besar Bahasa Indonesia (KBBI), santri adalah orang yang mendalami agama Islam;orang yang beribadah dengan sungguh - sungguh; orang yang soleh. ${ }^{7}$

Dari beberapa definisi diatas, dapat dipahami bahwa santri adalah murid yang belajar di pesantren dan didampingi oleh seorang Kyai dengan tujuan untuk mencari ilmu, khususnya ilmu agama. Santri juga disebut muta'allim (orang yang belajar).

Kyai adalah orang yang memiliki ilmu agama (Islam) plus amal dan akhlak yang sesuai dengan ilmunya. Menurut Saiful Akhyar Lubis, kyai adalah tokoh sentral dalam suatu pondok pesantren, maju mundurnya pondok pesantren ditentukan oleh wibawa dan kharisma sang kyai. ${ }^{8}$

Menurut Abdullah Ibnus Abbas, kyai adalah orang - orang yang mengetahui bahwa Allah SWT adalah dxat yang berkuasa atas segala sesuatu. ${ }^{9}$ Sebutan kyai sangat populer digunakan di Indonesia, khususnya di dunia pesantren. Kyai merupakan elemen sentral dalam kehidupan pesantren, tidak hanya karena kyai merupakan penyangga utama kelangsungan sistem pendidikan pesantren, tetapi juga karena sosok kyai merupakan cerminan dari nilai yang hidup di lingkungan komunitas pesantren. Kyai merupakan sosok yang paling dihormati di suatu pesantren karena kealiman dan keteladanannya. Kyai merupakan sanad ilmu tertinggi dalam lingkungan pesantren dari ilmu - ilmu yang diajarkan baik secara langsung maupun melalui ustadz - ustadz utusan kyai. Kyai juga disebut sebagai muta'allim (orang yang mengajar).

Istilah etika secara umum merujuk pada baik buruknya perilaku manusia. Etika juga diartikan sebagai perangkat aturan moral yang

6 Nurcholis Majid, Bilik - Bilik Pesantren; sebuah Potret Perjalanan, Jakarta: Paramadina, 1997), hlm. 20

7 Departemen Pendidikan dan Kebudayaan, Kamus Besar Bahasa Indonesia, (Jakarta: Balai Pustaka, 1998), cet. Ke -1, hlm. 783

8 Saiful Akhyar Lubis, Konseling Islami Kyai dan Pesantren, (Yogyakarta: ELSAQ Press, 2007), hlm. 169

${ }^{9}$ Hamdan Rasyid, Bimbingan Ulama; Kepada Umara dan Umat, Jakarta: Pustaka Beta, 2007), hlm. 18 
membedakan apa yang benar dan apa yang salah dari macam-macam tingkah lakuk mausia. Etika adalah bidang normatif yang menjelaskan secara tegas batas-batas wilayah yang tidak seharusnya dilakukan. Etika sebagai dasar baik dan buruk yang menjadi referensi pengambilan keputusan individu sebelum melakukan serangkaian kegiatan ${ }^{10}$. Etika dapat disimpulkan sebagai ilmu pengetahuan rohaniah, normatif dan teologis yang tidak dapat diukur dengan cara matematis. Etika lebih kepada pengetahuan tentanf kepandaian atau seni hidup secara baik (The art of good living).

Dari beberapa penjelasan diatas dapat ditarik kesimpulan bahwa etika santri kepada kyai adalah sikap atau perilaku yang seharusnya dilakukan oleh seorang santri kepada kyainya dalam proses pendidikan.

Pemikiran Al-Razi tentang Etika Murid kepada Guru dalam Tafsir Mafatih al-Gaib surat Al-Kahfi ayat 66-70

Dalam QS Al-Kahfi ayat 66 - 70, Allah berfirman :

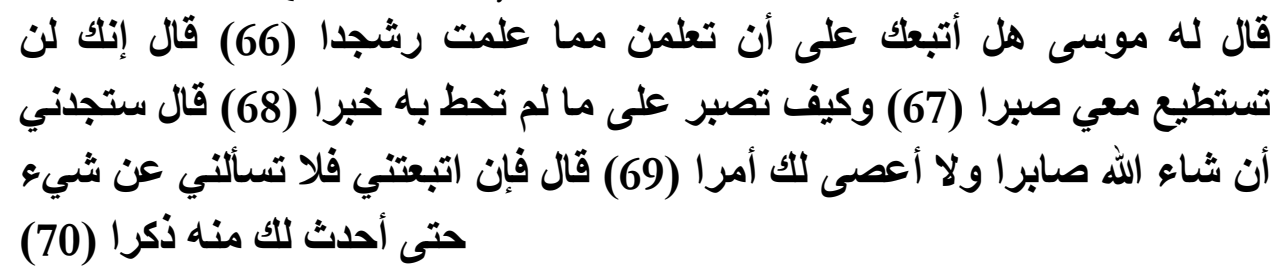

Artinya :

Musa berkata kepadanya (Khidir) : "Bolehkah aku mengikutimu agar engkau mengajarkan kepadakku (ilmu yang benar) yang telah diajarkan kepadamu (untuk menjadi) petunjuk?”, dia menjawab : "sesungguhnya engkau tidak akan sanggup sabar bersamaku. Dan bagaimana engkau akan dapat sabar atas sesuatu, sebab engkau belum mempunyai pengetahuan yang cukup tentang hal itu ?’. Dia (Musa) berkata : "Insya Allah akan engkau dapati aku orang yang sabar, dan aku tidak menentangmu tentang urusan apapun". Dia berkata: “jika engkau mengikutiku, maka janganlah engkau menanyakan kepadaku tentang sesuatu apapun, sampai aku menerangkannya kepadamu."

Penafsiran al-Razi dalam ayat 66 adalah sebagai berikut :

10 Muhammad Anas Ma'arif, "Hukuman (Punishment) Dalam Perspektif Pendidikan Di Pesantren," Ta'allum: Jurnal Pendidikan Islam 5, no. 1 (1 Juni 2017): 9, https://doi.org/10.21274/taalum.2017.5.1.1-20. 
Masalah pertama : Abu Umar dan Ya'qub membaca رشدا dengan fathah ro' dan syin dan Ibn Abas membaca dhommah ro' dan syin, para ulama lain membaca dhommah ro' dan sukun syin, Imam Qoval berkata lughot-lughot tersebut mempunyai makna satu seperti lafadz : رشدا - رشد, نكر أنمر ـ - dan lafadz رشك, شقم - شقم, شهل - شهل, عدم - عدم.

Masalah kedua: perlu didketahui bahwa ayat-ayat diatas tidak menunjukkan bahwa saat Nabi Musa hendak belajar kepada Nabi Khidhir beliau telah melakukan beragam etika :

Pertama : Nabi Musa A.S memposisikan dirinya sebagai seorang pengikut Nabi Khidhir dan sebagaimana yang diceritakan di Al Quran bahwa Nabi Musa AS berkata هل هلتبك "adakah aku bisa ikut denganmu?" hal ini mengisyaratkan sifat tawadhu yang amat tinggi. Dan dalam pendidikan islam sikap tawadhu murid kepada guru adalah sifat yang sangat diutamakan.

Kedua : Adapun permintaan izin Nabi Musa terhadao Nabi Khidir yang menunjukkan keikutsertaan beliau, ketika Nabi Musa berkata: "Wahai Nabi Khidir berkenankah anda untuk mengizinkan aku ikut denganmu?" dan ini menunjukkan ketawadhuan beliau yang sangat besar terhadap Nabi Khidir.

Ketiga : Ketika Nabi Musa berkata kepada Nabib Khidir على ان تعلمن "bersediakan untuk mengajariku ?" dab ini menunjukkan bahwa Nabi Musa masih jahl, dan beliau meminta izin kepada Nabi Khidir agar Nabi Khidir bersedia untuk mengajarinya.

Keempat : Nabi Musa berkata kepada Nabi Khidir معا علمت “ajarkan aku mengenai apa yang engkau ketahui" dan huruf min disini berfaedah menunjukkkan sebagian substansi dari teks yang ketika Nabi Musa meminta untuk diajari Nabi Khidir hanya sebagian ilmu saja, bukan semuanya dan disini juga menunjukkkan ketawadhuan beliau yang beliau ucapkan kepada Nabi Khidir "saya tidak menuntut meminta anda untuk menjadikan saya agar sama seperti anda dalam hal keilmuan, tetapi saya hanya meminta anda untuk menularkan sebagian saja dari ilmu anda. Diibaratkan seperti orang fakir yang meminta kepada orang kaya agar dikasih sebagian saja dari apa yang dipunyai oleh orang kaya tersebut.

Kelima : diayat yang sama معا علمت menunjukan pengakuan Nabi Musa bahwasanya Allah telah memberikan ilmu kepadanya.

Keenam : lafadz رشدا pada ayat ini diterangkan bahwasanya Nabi Musa juga meminta irsyad dan hidayah dalam rangka meluruskan ilmu dan mengharap 
petunjuk. Dan definisi dari irsyad adalah suatu perkara yang ketika belum/ tidak tercapai maka kesesatanlah yang didapat.

Ketujuh : lafadz تعلمني مما علمت رشدا di dalam ayat ini diterangkan Nabi Musa juga meminta agar beliau bisa mengamalkan ilmu layaknya Nabi Khidir mengamalkan ilmu yang telah diajarkan Allah padanya. Dan ini menunjukkan proses pembelajaran yang dilakukan oleh Nabi Musa sebagai wujud nikmat Allah yang telah dikaruniakan kepadanya. Sama halnya ketika beliau mensyukuri nikmat-nikmat Allah yang lain. Oleh karena itu sebagian ulama yang mengatakan "saya adalah hamba dari orang yang mengajariku meski yang diajarkan hanya 1 huruf."

Kedelapan : lafadz متابعة mengikuti suatu hal itu merupakan sebuah tindakan yang menyerupai apa yang dilakukan oleh orang lain. Mushonif memberikan gambaran seperti ini : ketika kita muslimin mengucapkan للاله الا لله dan orang yahudi dulu sebelum kita mengucapkan lafadz yang sama seperti apa yang kita sebut tadi, maka kita tidak wajib mengikuti orang-orang yahudi tadi karena ada kesamaan dalam mengucapkan lafadz tadi. Tetapi kita mengucappkan lafadz tersebut murni bertujuan uuntuk menegakkan dalil bahwasanya kaum muslimin wajib melafadzkannya. Bukan mengigkuti kaum yahudi. Adapun ketika kita melaksanakan sholat 5 waktu dengan menirukan nabi saw memang bertujuan untuk ikut kepada Nabi, kemudian mushonif menyambung bahwasanya dengan ayat hal aatbiuka. Dan di ayat ini menerangkan tentang kepatuhan Nabi Musa untuk mengikuti segala hal yang dilakukan oleh Nabi Khidir karena memang Nabi Musa melakukan hal tadi murni bertujuan untuk ikut dan mengikuti. Bisa diambil pelajaran dari hal ini bahwa murid harus patuh dan tidak diperbolehkan menentang ataupun menghindar dari perintah guru.

Kesembilan : lafadz تبعك اتك menerangkan tentang permintaan keikutsertaan/ kepatuhan terhadap sesuatu secara mutlak tanpa adanya qoyyid apapun bukan dalam hal tertentu saja.

Kesepuluh : dan hadits-hadits nabi juga sudah dijelaskan mengenai dua tokoh dalam ayat-ayat diatas bahwa : 1. Nabi Khidir merupakan nabi yang diutus untuk Bani Israil. 2. Nabi Musa adalah orang yang diberi mukjizat oleh Allah secara langsung tanpa melalui perantara siapapun, dan Allah juga memberikan berbagai macam mukjizat terhadap beliau selain kitab Tauret. Mempunyai derajat yang tinggi dan mulia karena sudah diberikan berbagai macam hal, seperti ketawadhuan terhadap Nabi Khidir. Dan itu 
menunjukkan bahwasanya Nabi Musa adalah seorang tholibul ilmi yang senantiasa bersungguh-sungguh dalam melakukan suatu hal, karena barang siapa yang bersungguh-sungguh dalam menajalani proses belajar, maka banyaklah ilmu yang akan didapat. Dan orang-orang yang mau bersungguhsungguh dalam mencari ilmu pasti mendapatkan banyak nilai plus yang akan didapatkannya. Adapun memuliakan guru, itu juga bentuk kesungguhan kita dalam menuntut ilmu, serta sangat dianjurkan bagi palajar.

Kesebelas : dalam ayat هل اتبعك على ان تعلمن menerangkan tentang urutan etika Nabi Musa belajar kepada Nabi Khidir yaitu : 1. Nabi Musa mengikuti apa yang dilakukan oleh Nabi Khidir. 2. Nabi Musa meminta Nabi Khidir untuk mengajarinya mengenai ilmu yang dimilikinya, bisa diambil kesimpulan dari keterangan ini bahwa nabi Musa sebelum berguru kepada Nabi Khidir, khdmah kepada nabi Khidir terlebih dahulu sebelum proses belajar dilaksanakan.

Kedua belas : lafadz هل اتبعك على ان تطمن dan nabi musa ketika belajar/ minta diajari Nabi Khidir sendiri tidak meminta apapun kecuali ilmu. Inilah ucapan Nabi Musa "saya tidak meminta apapun karena saya sudah ikut dengan anda, entah itu pangkat ataupun harta benda, melainkan saya hanya ingin menuntut ilmu dan belajar dengan anda"

Dalam ayat 66 diatas, Al-Razi telah mengelompokkan menjadi 2 masalah yang menunjukkan etika seorang santri yang akan meminta pengajaran kepada kyai, yaitu :

1. Mempunyai akhlak yang baik. Akhlak ini ditujukkan Nabi Musa dengan sebuah ucapan yang halus seperti hal attbiuka, hal ini mengisyaratkan sifat tawadhu yang amat tinggi.

2. Meminta izin kepada kyai.

3. Merasa bodoh walaupun sebenarnya lebih pandai.

4. Meminta diajarkan ilmu.

5. Yakin bahwa Allah menganugerahkan ilmu yang lebih kepada guru.

6. Pasrah dan meminta hidayah kepada Allah.

7. Mensyukuri nikmat Allah dengan cara bersungguh-sungguh dalam menuntut ilmu.

8. Patuh kepada kyai secara mutlak bukan karena hal-hal tertentu.

9. Khidmah dan siap melayani guru.

10. Tidak meminta selain ilmu

Adapun pendafsiran terhadap ayat 67-68 sebagai berikut : 


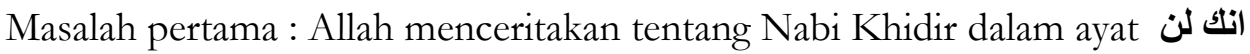
تشتطيعdisini ada beberapa masalah. Masalah pertama : perlu diketahui bahwa pelajar terbagi menjadi 2 bagian, yaitu 1. pelajar yang tidak tahu ilmu dan tidak mempraktekkan apa yang dia dengan dan tidak mempunya prinsip dan kejanggalan. 2. pelajar yang mempunyai berbagai ilmu dan mempraktekannya dan mempunyai prinsip mengetahui kejanggalan-kejanggalan terhadap masalah yang ia jumlai.

Murid nomor 2 diatas ingin selalu bergaul dengan orang lain yang lebih unggul darinya, agar dia bisa semakin bertambah lebih baik dan menduduki posisi kesempurnaan. Pelajar tersebut sangatlah susah. Karena terkadang ketika melihat atau mendengar sesuatu tidak serta merta setuju terhadap suatu hal kecuali memang perkara yang baru tersebut sudah benar-benar nyata dan tidak ada keraguan lagi. Adapun murid yang nomor 1 tidak seperti itu, ia senantiasa memandang atau melihat sesuatu perkara itu bukan hanya dari sisi luarnya saja. Akan tetapi memandang dan menimbang segi dalamnya dari suatu permasalahan.

Oleh karena itu pelajar nomor2 akan sulit mencapat derajat muta'allimin karena banyaknya macam perdebatan, pertentangan dan perselisihan dalam benaknya. Dan terkadang sulit untuk memahami ucapan atau perkataan yang keluar dari lisan orang yang sudah ahli dalam berilmu. Kalau hanya sekedar mengigkuti perkataan orang alim saja, pelajar tersebut hanya akan bertahan sebentar. Allah menggambarkan hal tersebut dalam ayat innaka lantastu, betapa susahnya untuk mengikuti Nabi Khidir sehingga muncul berbagai وكيف تصبر macam pertentangan dan perdebatan dan disambung dengan ayat ولى ما لمتحط به صبرا Allah memberi isyarat dengan yat ini, bahwa Nabi Musa bukanlah orang yang mengetahui hakikat dari segala sesuatu. Sebagaimana yang mushonif sebuttkan tadi jika hanya mengikuti dua atau tiga kali maka hanya akan menimbulkan pertanyaan, sulit untuk melakukan proses pembelajaran dan berujung pada ketikdak mampuan belajar sehingga tidak mendapatkan ilmu.

وكيف تصبر على ما لمتحط به صبرا dengan pendafsiran bahwasanya kemampuan itu tidak akan didapatkan sebelum melakukan suatu tindakan dan mayoritas ulama berpendapat "kalaupun saja kemampuan bisa didapatkan sebelum melakukan suatu tindakan". Imam Jiba'i memberikan pendapat mengenai ayat tadi yang dimaksud ayat tadi itu adalah kesulitan yang dirasakan Nabi Musa untuk bisa 
bersabar terhadap Nabi Khidir, bukan berarti Nabi itu tidak mampu bersabar. Akan tetapi jika ditinjau dari segi 'urf (kebiasaan), perkataan "fulan itu tidak bisa melihat orang lain" bukan serta merta si fulan tidak mampu untuk melihat orang lain. Pendapat ini mirip dengan ayat maa kaanuu laa yastathiuuna, yang berarti terdapat kesulitan untuk mendengarkan suatu hal, kalau ada pendapat yang berpendapat "ini keluar dari teks dhohir dan tiadanya dalil mengenai hal tersebut" pendapat seperti ini tidak diperkenankan. Dan mushonif memberikan komentar mengenai pengukuhan dalil yang diambil dari kalangan mufassirin.

Dari tafsiran diatas dapat disimpulkan bahwa santri dibagi menjadi dua yaitu adakalanya dia bodoh dan pandai. Murid yang bodoh biasanya penurut, selalu melakukan apa yang diperintahkan oleh kyai dan tidak banyak membantah karena kebodohannya bukan berarti dia tidak tau apa-apa. Oleh sebab itu, santri ini akan rajin mengulang pelajaran. Selanjutnya santri pandai maksudnya dia sudah merasa pandai sehingga terkadang menyepelekan kyainya. Hal ini akan menimbulkan rasa sombong sehingga sulit baginya untuk mencapat derajat muta'alimin karena banyak berdebat sebagaimana yang dicontohkan Nabi Musa yang notabenenya beliau adalah orang yang pandai.

Pendafsiran pada ayat 69-70 sebagai berikut:

Masalah pertama : oleh para pemitnah, ayat ini digunakan sebagai dalil bahwa para nabi itu tidak memiliki sifat maksum. Mereka berpendapat bahwa firman Allah yang menceritakan tentang penilaian Nabi Khidir kepada Nabi Musa, dan jawaban nabi Musa terhadap penilaian Nabi Khidir keduanya merupakan sebuah bentuk kebohongan. Dengan demikian sebuah kebohogan ini dapat dilakukan oleh para Nabi. Jawaban atas tuduhann ini adalah dengan mengartikan penilaian Nabi Khidir sebagai sebuah penilaian yang biasanya dilakukan oleh orang yang merasa orang lain tidak mampu menahan sabar ketika dihadapkan pada hal-hal lain yang belum dimengerti dan tidak sesuai dengan pengetahuan yang dimiliki oleh orang tersebut.

Masalah kedua : redaksi ان كان Sنl merupakan sebuah redaksi yang mengindikasikan sebuah keraguan. Dengan demikian berarti firman Allah yang berbunyi ستجدني ان شاء الله صابر hal ini berarti ada sebuah keraguan dalam diri Nabi Musa apakah Allah menghendakinya sebagai orang yang sabar atau tidak. Dan tidak diragukan lagi bahwa kesabaran dalam kondisi tawaqquf (sebuah kondisi yang menuntut seseorang untuk berhenti pada 
batasan pengetahuannya dan tidak memberikan penilaian terhadap hal-hal yang belum ia ketahui) merupakan sebuah kewajiban. Dari sini dapat ditarik kesimpulan bahwa terkadang Allah swt tidak menghendaki seorang hamba untuk melakukan kewajibannya.

Adapun kelompok mu'tazilah, mereka berpendapat bahwa pada dasarnya firman Allah diatas merupakan sebuah bentuk etika seseorang saat dia melakukan sebuah aktifitas nanti. Oleh karena itu diucapkan kalimat ini.

Masalah ketiga : firman Allah ولا اعصى لك امرا menunjukkan arti bahwa secara spontanitas sebuah perintah itu wajib dikerjakan. Arti tersebut didasarkan pada sebuah kesimpulan yang menegaskan bahwa seseorang yang tidak mengerjakan sebuah perintah berarti dia adalah orang yang durhaka. Sedangkan seseorang yang durhaka itu berhak mendapatkan siksaan.

Masalah keempat : firman Allah tentang perkataan وكيف تصبر على ما لم تحط به خيرا merupakan sebuah perkataan yang memberikan penilaian bahwa keilmuan dan pengertian yang dimiliki oleh Nabi Musa itu sedikit. Sedangkan ستجدني إن شاء الله صابرا ولا أعصي لك أمرا jawaban Nabi Musa yang berbunyi merupakan sebuah gambaran sikap rendah diri Nabi Musa sekaligus kesiapan beliau yang sempurna dalam menerima arahan. Dan semua itu menunjukkan bahwa kewajiban seoran murid adalah memperlihatkan sikap rendah diri semaksimal mungkin. Adapun saat seorang guru merasa bahwa berlaku keras itu dapat memberikan kebaikan kepada murid dapat memberikan kebaikan untuknya, maka sang guru berkewajiban untuk mengingat muridnya. Karena ketidak adanya peringatan itu dapat menjerumuskan murid dalam ketertipuan dan kesomobngan dan sudah barang tentu hal tersebut akan menghalanginya untuk semangat belajar. Setelah mengetahui jawaban Nabi Musa tersebut, Nabi Khidir menjawab : قال فان اتبعني فلا تسألني عن شيء حتى احلث للك منه نكرا janganlah kau bertanya padaku mengenai hal-hal yang belum kau ketahuiu arahannya yang kau lihat dariku, sehingga aku sendirilah yang akan memulai untuk mengajarimu dan memberitahumu mengenai hal-hal tersebut. Lafadz

فلا تسألني dibaca berbeda-beda oleh para imam Qiroah diantaranya Imam Amir, Imam Nafi' dan lain-lain, tapi semuanya memiliki makna yang sama.

Ayat diatas menguatkan ayat sebelumnya dengan cara meyakinkan guru bahwasanya nabi Musa memposisikan benar-benar sebagai murid yang ingin belajar kepada guru yang lebih tau walau sang murid lebih tau dari gurunya. Maka وكيف تصبرو merupakan perkataan yang memberikan penilaian bahwa keilmuan dan pengertian sangat dimiliki oleh Nabi Musa itu sedikit. 
Sedangkan jawaban Nabi Musa yang berbunyi : ستجدني merupakan gambaran sikap rendah diri Nabi Musa sekaligus kesiapan beliau yang sempurna dalam menerima arahan Nabi Khidir dan semua itu menunjukkan bahwa kewajiban seorang murid adalah memperlihatkan sikap rendah diri semaksimal mungkin.

\section{Relevansi penafsiran al Razi atas QS Al Kahfi ayat 66 - 70 dalam konteks Etika Santri Kepada Kyai}

Dalam dunia pendidikan khususnya pendidikan pesantren, etika merupakan hal paling utama yang harus dimiliki oleh seoran gsantri. Dari etika yang baik inilah kemudian dia dapat belajar dan berproses dengan baik sehingga tujuan pencarian ilmunya dapat terdcdapat. Etika seorang muta'alimin kepada mu'allimin yang terdapat dalam tafsir surat Al Kahfi ayat 66 - 70 haruslah diterapkan dalam dunia pendidikan, tidak terkecuali di pesantren, etika santri kepada kyai.

Al Razi dalam tafsir tersebut menitik beratkan pada proses sebelum belajar dimulai. Nabi Khidir terlebih dahulu menguji nabi Musa sebelum belajar kepada beliau seperti tes masuk di sebuah lembaga pendidikan. Hal ini mengisyaratkan utamanya posisi akhlak dan etika dalam suatu proses belajar, apapun.

Secara rinci gagasan Fahrudin Al Razi tentang etika santri kepada kyai dapat dijabarkan sebagai berikut :

1. Tawadhu sebagaimana majas yang digunakan Nabi Musa saat meminta untuk balajar kepada Nabi Khidir yang mengisyaratkan ketawadhuan.

2. Meminta izin untuk diperbolehkan belajar.

3. Merasa lebih bodoh dari kyai.

4. Meminta kepada kyai agar bersedia mengajari sebagian ilmu.

5. Berkeyakinan bahwa Allah menganugerahkan ilmu yang lebih kepada kyai.

6. Tawakkal dan meminta hidayah kepada Allah.

7. Mensyukuri nikmat Allah dengan cara bersungguh-sungguh dalam belajar.

8. Patuh kepada kyai secara mutlak.

9. Khidmah dan siap melayani kyai dalam keadaan apapun.

10. Tidak meminta kepada kyai selain ilmu. 
Meskipun banyak mufassir yang menjelaskan bahwa surat al Kahfi ayat 66 - 70 ini menjelaskan tentang pendidikan tasawuf, pemikiran ini sebenarnya sangat cocok untuk diterapkan dalam pendidikan apapun dan lembaga manapun termasuk pesantren.

\section{PENUTUP}

Al Quran merupakan risalah terbaik yang pernah diwahyukan Allah swt kepada umat manusia, penyempurna segala bentuk wahyu yang pernah diturunkan sebelum-sebelumnya. Salah satu kemukjizatannya adalah teks al quran yang tidak pernah dan tidak akan pernah berubah sejak berabad-abad yang lalu diturunkan kepada Rosulullah saw yang mulia, tetapi isi kandungan dalam Al-Quran selalu mampu menjawab dan memberi petunjuk atas segala problematika yang dihadapi manusia, shabih fi kulli zaman wa makan. Tidak terkecuali dalam membahas proses pendidikan sebagai penentu kemajuan kehidupan umat, Al- Quran pun memberikan tatanan detil termasuk mengenai etika santri kepada kyai, sebagai way of life, sudah sepatutnya umat Islam membumikan nilai-nilai tersebut dalam kehidupan. Tafsir QS Al Kahfi ayat 66 - 70 menurut Fahrudin Al Razi dalam kitab Mafatih al Gaib banyak menjelaskan tentang proses Nabi Musa memulai dan belajar kepada Nabi Khidir. Psoses tersebut memuat banyak poin-poin etika seorang muta'allimin kepada mu'allimin yang menjadi suri tauladan bagi kehidupan, utamanya dalam dunia pendidikan. Banyaknya poin etika yang harus diperhatikan sebelum seorang mulai belajar mengisyaratkan betapa pentingnya etika diatas segalanya.

Etika seorang santri kepada kyai yang termaktub dalam tafsir QS Al Kahfi ayat 66 -70 oleh Al Razi dalam Mafatih al Gaib yaitu :

a) Tawadhu.

b) Meminta izin untuk diperbolehkan belajar.

c) Merasa lebih bodoh dari kyai.

d) Meminta kepada kyai agar bersedia mengajari sebagian ilmu.

e) Berkeyakinan bahwa Allah menganugerahkan ilmu yang lebih kepada kyai.

f) Tawakal dan meminta hidayah kepada Allah.

g) Bersungguh-sungguh

h) Patuh kepada kyai secara mutlak

i) Khidmah

j) Tidak meminta kepada kyai selain ilmu. 


\section{REFERENSI}

Akbar, Lutfi, Prinsip Pendidikan Karakter dalam Al-Quran; Studi Atas Kisah Nabi Musa dan Nabi Khidbir dalam Qs Al Kabfi: 60 - 82, Skripsi, Surakarta: Fakultas Ushuluddin dan Dakwah IAIN Surakarta, 2017. Al - Abrasyi, Moh. Athiyah, Dasar - dasar Pokok Pendidikan Islam, Terj. A. Gani dam Johar bahry,Jakarta: Bulan Bintang, 1970.

al-Dzahabi, Muhammad Husain , Al-Tafsir wa Al-Mufassirun, Kairo: Maktabah Wahbah

al-Ghazali, Imam,Ihya' Ulumuddin, Semarang: CV. Faizan.1979.

al-Qaththan, Mana' Khalil, Pengantar Studi Ilmu Al-Quran, terj. Aunur Rafiq El-Mazni , Jakarta: Pustaka Al-Kautsar, 2008.

Litera AntarNusa, 1992

AlQur" an Tajwid dan Terjemah, Bandung: CV Diponegoro, 2010.

al-Razi, Fahruddin, Roh itu Misterius, terj. Muhammad Abdul Qadir Al-Kaf, Jakarta: Cendikia Centra Muslim, 2001.

-------Tafsir al-Kabir wa Mafatih alGhaib, Bairut: Dar al-Fikr, 1990

al-Zarnuji, Syeikh, Ta"limul Muta" allim, Semarang: Pustaka Alawiyyah.

Ash-Shiddieqy, M. Hasbi, Sejarah dan Pengantar Ilmu Al-Quran/Tafsir .Jakarta: Bulan Bintang, 1990.

Ayazi, Muhammad Ali, al-Mufassirun Hayatubum wa Manhajubum, Taheran: Mu'assasah al-Taba'ah wa al-Nashr, $1415 \mathrm{H}$.

Departemen Pendidikan dan Kebudayaan, Kamus Besar Bahasa Indonesia, cet. Ke - 1, Jakarta : Balai Pustaka, 1998.

Hamka, Tafsir al-Az̧har, Jakarta: Pustaka Panjimas, 1982. Juz XV

Haedari, HM. Amin, dkk, Masa Depan Pesantren; dalam tantangan modernitas dan tantangan komplesitas global, Jakarta; IRD Press, 2004.

Lubis,Saiful Akhyar , KonselingIslami Kyai dan Pesantren, Yogyakarta; ELSAQ Press,2007.

Madjid, Nurcholis, Bilik - bilik Pesantren; Sebuab Potret Perjalanan, Jakarta; Paramadina, 1997.

Mahmud, Mani' Abdul Halim, Metodologi Tafsir: Kajian Komprehensif Metode Para Abli Tafsir, Jakarta: PT. Raja Grafindo.

Maksum, Moh Toha, Kisah Musa dan Khidhir dalam Surat Al Kabfi; Studi atas Penafsiran Al-Qusyairi dalam Kitab Lataiful Isyarat, skripsi, Yogyakarta: Fakultas Ushuluddin UIN Sunan Kalijaga, 2009. 
Vol. 2 No 22019

Ma'arif, Muhammad Anas. "Hukuman (Punishment) Dalam Perspektif Pendidikan Di Pesantren." Ta'allum: Jurnal Pendidikan Islam 5, no. 1 (1 Juni 2017): 1-20-20. https://doi.org/10.21274/taalum.2017.5.1.1-20.

Muzakki, Kholid Akhmad, Ahmad Rizza Firdaus, dan Annisa' Fatmayanti. "Tindak Tutur Tak Langsung Dalam Surat Al-Kahfi (Kajian Analisis Pragmatik)." Nað̧huna: Jurnal Pendidikan Islam 1, no. 1 (16 Agustus 2018): 96-121. https://doi.org/10.31538/nzh.v1i1.44.

Masngudi, Pola Hubungan Guru- Murid dalam Surat Al Kabfi ayat 65 - 70 dan Implementasinya dalam Pendidikan Islam, Skripsi, Semarang: Fakultas Tarbiyah IAIN Walisongo Semarang, 2006.

Nandya,Anisa, Etika Murid Terbadap Guru; Analisis Kitab Ta'limul Muta'allim Karangan Syaikh Al Zarnuji, Skripsi, Salatiga: Fakultas Tarbiyah STAIN Salatiga, 2013.

Natsir,M. , Capita Selecta, Jakarta: Bulan Bintang, 1973.

Rasyid, Hamdan, Bimbingan Ulama; Kepada Umara dan Umat, Jakarta; Pustaka Beta, 2007.

Shihab, M. Quraish, Tafsir Al-Misbah, Jakarta: Lentera Hati, 2012

Singarimbun, Masri dan Sofyan Efendi, Metode Penelitian Survei, Jakarta: LPE3S ,1982.

Surachmat,Winarno, Dasar Tebnik Research, Bandung: Tarsit, 1997.

www.bps.go.id diakses pada 28 Juli 2019 pukul 22:51 WIB

www.pendis.kemenag.go.id diakses pada 24 Desember 2018 pukul 23:33 WIB 